\title{
Science to Support Water-Resource Management in the Upper Roanoke River Watershed
}

Tlooding, excessive sedimentation, and Thigh bacteria counts are among the most challenging water resource issues affecting the Upper Roanoke River watershed. These issues threaten public safety, impair the watershed's living resources, and threaten drinking water supplies, though mitigation is costly and difficult to manage.

Urban development, land disturbance, and changing climatic patterns continue to challenge watershed managers who are tasked with protecting and improving the water quality of the Upper Roanoke River watershed. The U.S. Geological Survey (USGS) helps watershed managers meet these demands by providing high-quality data and analyses designed to inform watershed restoration activities.

\section{Current USGS Projects}

- Quantify the amount of suspended sediment delivered from the City of Roanoke to the Roanoke River.

- Determine physical and chemical water-quality impacts from the construction of a natural gas pipeline.

- Characterize spatial and temporal precipitation patterns in the City of Roanoke.

The USGS is studying in-stream effects from the construction of a natural gas pipeline at numerous stream crossings throughout the Upper Roanoke River watershed using real-time water-quality monitors, as pictured (right).

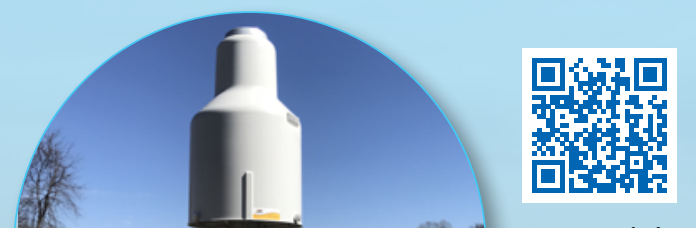

The USGS measures precipitation throughout the City of Roanoke from monitoring stations like the one pictured (left). These data are delivered online in near-real-time and reveal large amounts of rainfall variability throughout the city. During the 2018 water year (October 1, 2017-September 30, 2018), 33 to 44 inches of rainfall were measured. Visit the Virginia Real-Time Precipitation Mapper

at https://va.water.usgs.gov/webmap/precip_va/.

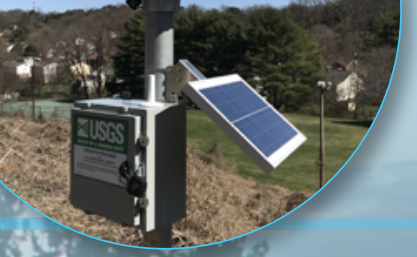

The USGS studied the effects of the Roanoke River Flood Reduction Project and found no significant changes to the sediment sources or composition. This study was driven by the need to protect the habitat of the endangered Roanoke River logperch (above). https://pubs.er.usgs.gov/publication/sir20155111

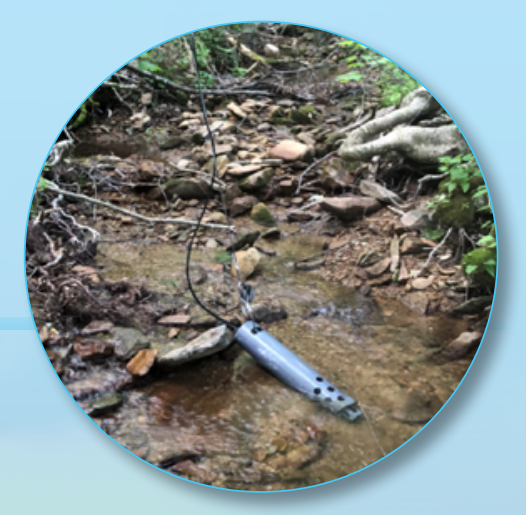

\section{Lick Run watershed 2018 water year suspended sediment load}

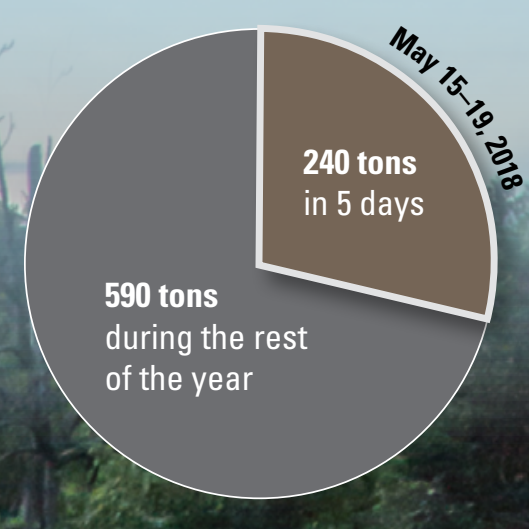

The USGS estimates suspended-sediment loads in streams throughout the City of Roanoke. In the Lick Run watershed, 7 inches of rain fell over 5 days in May 2018 and mobilized 30 percent of the annual suspended-sediment load. This storm demonstrated how heavy rainfall events can quickly move large amounts of sediment. 
Real-time data are collected from 17 monitoring locations throughout the Upper Roanoke River watershed and from 10 precipitation gages within the City of Roanoke. All data are transmitted to the web and available in numerical and graphical form (below) through the National Water Information System at https://waterdata.usgs.gov/nwis/.
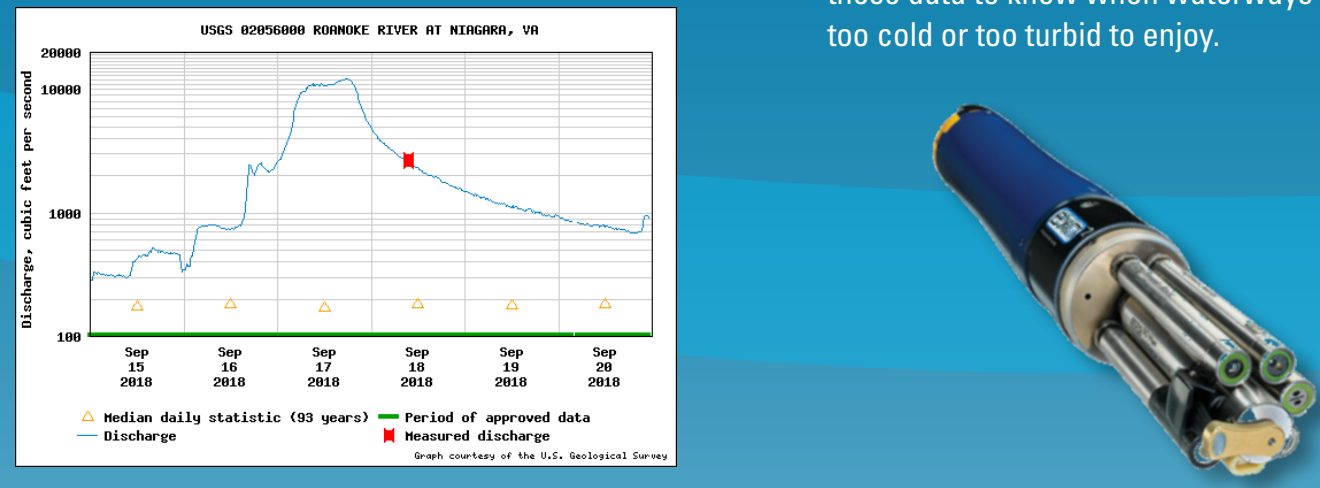

Real-time water-quality data are

measured from in-stream instrumentation

(below). Scientists and managers

use real-time water-quality data to

understand the quantity and sources of

sediment delivered to streams and rivers.

Anglers, boaters, and swimmers use

these data to know when waterways are too cold or too turbid to enjoy.

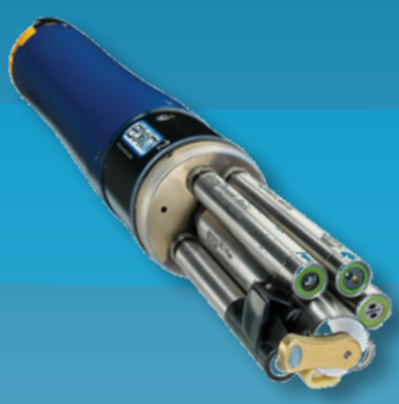

Streamflow, pictured (below) with a staff plate, is measured in real-time to provide fundamental hydrologic data for watershed recreation and management. These data are used by the National Weather Service to issue flood warnings.

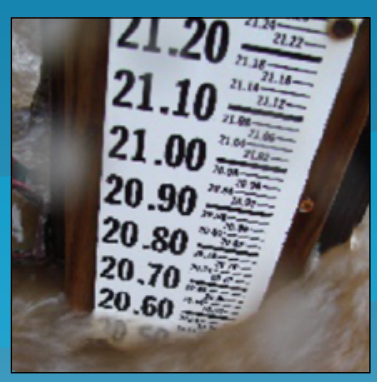

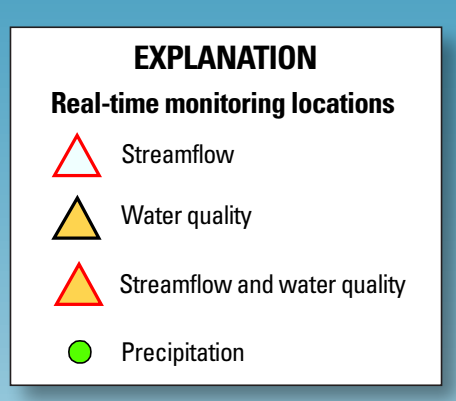
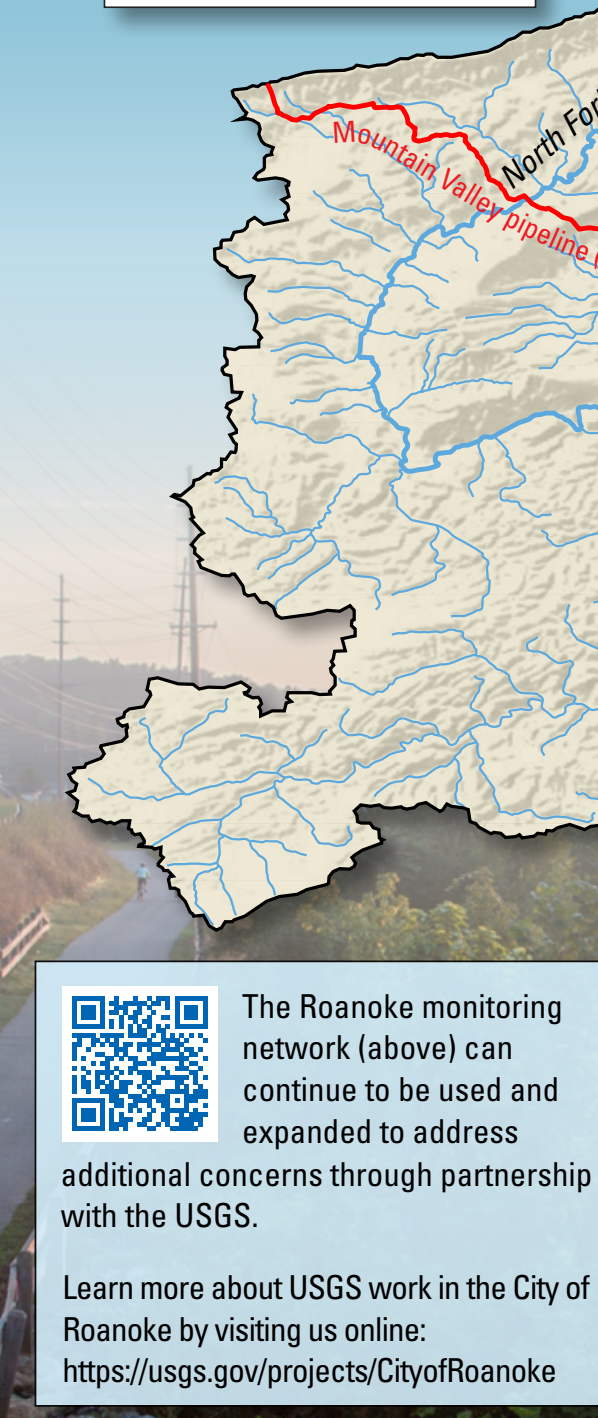

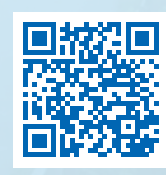

The Roanoke monitoring network (above) can continue to be used and expanded to address additional concerns through partnership with the USGS.

Learn more about USGS work in the City of Roanoke by visiting us online:

https://usgs.gov/projects/CityofRoanoke 